PRODUÇÃO ANIMAL

\title{
EFFECT OF SHEARING DURING PREGNANCY ON PRODUCTIVE PERFORMANCE IN THE POST-PARTUM PERIOD OF EWES ON EXTENSIVE HUSBANDRY
}

\section{EFEITO DA ESQUILA DURANTE A GESTAÇÃO SOBRE O DESEMPENHO PRODUTIVO NO PERÍODO PÓS-PARTO EM OVELHAS MANTIDAS EM MANEJO EXTENSIVO}

\author{
Viviane Marques Guyoti ${ }^{1}$ \\ Mariana de Souza Farias ${ }^{1}$ \\ Magnus Larruscaim Dalmolin ${ }^{1}$ \\ César Henrique Poli² \\ Verônica Schmidt² \\ Felix Diaz Gonzalez ${ }^{2}$

\begin{abstract}
1Pós-graduandos da Universidade Federal do Rio Grande do Sul, Porto Alegre, RS, Brasil. 2Professores Doutores da Universidade Federal do Rio Grande do Sul, Porto Alegre, RS, Brasil. felixgonzalez.ufrgs@gmail.com
\end{abstract}

\begin{abstract}
The use of shearing during pregnancy has been described as a tool for improving productivity in sheep and for minimizing perinatal mortality in lambs through the increase of fetal development. This study assessed the effect of shearing around 74 days of gestation on the productive performance of ewes and lambs during the first month of life. Forty Corriedale ewes were inseminated in autumn in Southern Brazil. All ewes were kept together at the same pasture under extensive husbandry conditions. The ewes were randomly separated into two treatment groups: twenty animals were completely sheared at $74 \pm 6$ days of pregnancy, and twenty were kept without sheared during pregnancy, composing the control group. Ewes and their lambs were evaluated at three different times during the experiment: at birth, between 15 and 21 days post-partum and between 22 and 45 days post-partum. Ewes had their body condition score, body weight, placental weight, milk production and serum concentrations of beta-hydroxybutyrate measured, while lambs had hematocrit, hemoglobin, and plasma lactate and glucose, as well as body weight at birth and until wean determined. Values of hematocrit and hemoglobin were lower and body weight at birth and at wean was higher in the group of lambs born from sheared ewes. Placenta weight was higher in sheared ewes. Body condition score and beta-hydroxybutyrate showed no differences between groups. Milk production of sheared ewes $(1.26 \mathrm{~L} /$ day) was higher than in control group (0.93 L/day). Shearing ewes at 74 days of pregnancy was efficient for the better development of lambs at post-birth, reducing perinatal mortality rates.
\end{abstract}

Keywords: beta-hydroxybutyrate; lambs; milk yield; metabolism; placenta weight. 


\section{Resumo}

O uso da esquila durante a gestação tem sido descrita em ovelhas como ferramenta para aumentar a produtividade e minimizar a mortalidade perinatal em cordeiros por aumentar o desenvolvimento fetal. No presente estudo foi avaliado o efeito da esquila em torno dos 74 dias de gestação sobre o desempenho produtivo de ovelhas e no peso de seus cordeiros durante o primeiro mês de vida. Quarenta ovelhas Corriedale foram encarneiradas no outono do Sul brasileiro, sendo mantidas sob a mesma pastagem em condições extensivas. As ovelhas foram distribuídas aleatoriamente em dois grupos de tratamentos, sendo vinte ovelhas esquiladas aos $74 \pm 6$ dias de gestação e vinte mantidas sem esquila durante a gestação, compondo o grupo controle. Ovelhas e respectivos cordeiros foram avaliados em três períodos: no dia do parto, entre 15 e 21 dias pós-parto e entre 22 e 45 dias pósparto. Nas ovelhas, foram medidos o escore de condição corporal, o peso corporal e da placenta, a produção do leite e a concentração sérica de beta-hidroxibutirato, enquanto nos cordeiros foram determinados hematócrito, hemoglobina e concentrações plasmáticas de lactato e glicose, além de peso corporal ao nascimento até o desmame. Os valores médios de hematócrito e hemoglobina foram menores e o peso corporal ao nascimento e ao desmame foi maior no grupo de cordeiros nascido de ovelhas esquiladas. $\mathrm{O}$ peso médio da placenta foi maior nas ovelhas esquiladas. $\mathrm{O}$ escore de condição corporal e a concentração de beta-hidroxibutirato não evidenciaram diferenças entre os grupos. A produção leiteira de ovelhas esquiladas $(1,26 \mathrm{~L} /$ dia) foi maior que no grupo controle (0,93 L/dia). A esquila de ovelhas em torno dos 74 dias de gestação mostrou-se eficiente para o melhor desenvolvimento de cordeiros na fase pós-nascimento de forma a contribuir na diminuição da taxa de mortalidade perinatal.

Palavras-chave: beta-hidroxibutirato; cordeiros; metabolismo; peso da placenta; produção de leite.

Recebido em: 12 dezembro 2014

Aceito em: 24 fevereiro 2015

\section{Introduction}

Perinatal death in lambs, occurring immediately before, during or up to 28 days after birth, is one of the main causes of limited productivity in flocks from southern Brazil ${ }^{(1,2)}$. In Rio Grande do Sul State, birth weight of lambs vary from 2.9 to $3.7 \mathrm{~kg}$ and mean losses in perinatal period are due to the exposition-inanition complex, associated to low weight at birth ${ }^{(2)}$. In New Zealand, perinatal death rate is over $80 \%$ in lambs born with body weight lighter than $2.0 \mathrm{~kg}$ and the survival rate is higher in animals born with a body weight heavier than $3.0 \mathrm{~kg}^{(3)}$.

Some strategies can be adopted in order to diminish perinatal death in lambs, such as improving weight at birth ${ }^{(4)}$, which involves enhancing fetal development ${ }^{(5)}$, especially in periods of scarce grass or in winter. For this purpose, shearing during gestation has been used as an alternative, because it alters the metabolism and the placenta of ewes ${ }^{(6)}$. Shearing ewes during gestation enhanced in $17 \%$ the survival rate of lambs by ameliorating the weight at birth ${ }^{(7,8)}$, which may vary from $5.4 \%$ to $7.8 \%$ compared with lambs born from non-sheared ewes ${ }^{(9)}$. Morris and McCutcheon $^{(10)}$ and Ribeiro et al. ${ }^{(11)}$ verified a mean increase of body weight at birth of 700 and $710 \mathrm{~g}$ in lambs from ewes that were sheared between 70 and 74 days of pregnancy, respectively. 
Mellor ${ }^{(12)}$ suggested the best time for shearing in order to obtain the higher placenta development in ewes is around 74 days of pregnancy. A probable explanation for the effect of shearing is the stimulus for a greater food intake by the sheep exposed to cold temperature ${ }^{(13)}$.

Lamb nutrition during the first four weeks of life depends exclusively from maternal milk ${ }^{(14)}$; thus, body weight gain of the lamb in that period is a function of the milk produced by the ewe ${ }^{(15)}$. Better milk yield has been observed in sheep sheared at 100 days of pregnancy compared to non-sheared sheep ${ }^{(16)}$; however, the physiological mechanisms involving such effect are not clear.

The present work aimed at evaluating the effect of shearing ewes raised in extensive grazing system, around 74 days of gestation, on the weight and development of their lambs during the first month of life.

\section{Material and methods}

The Ethical Committee of the Federal University of Rio Grande do Sul (project N. 21910) approved all procedures in this experiment. The study was conducted at an experimental farm located in the state of Rio Grande do Sul, southern Brazil (latitude $30^{\circ} 05^{\prime \prime} 00^{\prime \prime}$ and longitude 50 47'00"). A total of 40 Corriedale pregnant sheep, aged between 2 and 5 years, mean weight of $51 \mathrm{~kg}$, and their respective born lambs (20 in the sheared group, 23 in the control group) were used. The sheep were randomly divided into two treatment groups, each one composed by 20 ewes. At $74 \pm 6$ days of pregnancy, one group was submitted to complete shearing, with an appropriate wool cutting machine at $32 \mathrm{~mm}$ of length. The other group did not suffer shearing and constituted the control group. All animals were maintained on an extensive grazing system with native forage, ryegrass (Lolium multiflorum) and white oats (Avena sativa). During the course of the experiment, two lambs of the control group died by hypothermia on the first day of life and one ewe and its lamb of the sheared group died as consequence of an abortion.

During lambing, all sheep were observed until complete placental expulsion. The placentas were weighed using digital scales (Angyu, China). On the day of birth, blood samples from lambs were obtained using vacuum plain tubes (Vacutainer, BD Diagnostics) to determine lactate and glucose levels. The animals were thereafter evaluated in another two periods in addition to the day of lambing: between 15 and 21 days and between 22 and 45 days post-partum. In those periods, body condition score was recorded for each ewe using the technique described by Russel ${ }^{(17)}$, with values varying from 1 (very thin ewe) to 5 (very fat ewe). In addition, blood samples were collected through jugular venipuncture using vacuum plain tubes (Vacutainer, BD Diagnostics) in order to determine serum concentration of beta-hydroxybutyrate (BHB). At the same periods, lambs were sampled using vacuum tubes with EDTA $\mathrm{K}_{2}$ (Vacutainer, BD Diagnostics) in order to determine de hematocrit and hemoglobin. Milk yield of ewes was measured in two periods: 15-21 days and 22-45 days of lactation. Partial milk yield was determined in the morning by manual milking of each udder after 8 hours of lamb separation and total milk yield was calculated by using the value obtained extrapolated for 24 hours ${ }^{(18)}$.

Hematological analysis were performed with $2 \mathrm{~mL}$ of blood for hematocrit determination using microcentrifuge $(11.700 \mathrm{~g}$ for 10 minutes $)$ and hemoglobin determination using cyanometahemoglobin technique (Labtest) by a semiautomatic spectrophotometer equipment (Metrolab 1600, Winner Diagnostic). For biochemical analysis, serum samples were obtained from 
$3 \mathrm{~mL}$ of blood centrifuged at $3.000 \mathrm{~g}$, during 10 minutes, at $24{ }^{\circ} \mathrm{C}$, and then separated and stored at $-20{ }^{\circ} \mathrm{C}$ until determination. Lactate, glucose and BHB were determined by spectrophotometry using specific reagent kits (Randox for BHB and Labtest for glucose and lactate).

The data were analyzed through the software SPSS(R) version 17.0 adopting a significance level of $5 \%$. Shapiro-Wilk test was used for verifying the normality of the variables. Comparison of data between the two groups was done using Student $t$ test, when the parameters were adjusted to normality, or using non-parametric Mann-Whitney test for non-normal data.

\section{Results}

Table 1 shows lambs' body weight in three different periods after birth. Lambs born from sheared ewes presented higher body weight in all the observed periods $(p=0.01)$. Values of hematocrit and hemoglobin were lower $(\mathrm{p}<0.05)$ in the group of lambs from sheared ewes. Lactate and glucose values did not show any difference. Body weight at birth was $930 \mathrm{~g}$ higher in lambs from sheared ewes. Those lambs showed a mean weight gain $16.4 \%$ higher until 45 days of life compared to the control group. During all the evaluated period, the mean difference of body weight was $1.98 \mathrm{~kg}$ higher in lambs from sheared ewes $(\mathrm{p}<0.05)$.

The results obtained in the groups of ewes are given in Table 2. Mean placenta weight and milk yield were significantly higher in the sheared ewes. Mean placenta weight of those sheep was $105 \mathrm{~g}$ higher and the mean milk yield was $323.5 \mathrm{~mL} /$ day higher than in non-sheared ewe ( $<<0.05)$. Body condition score and BHB concentration did not show any difference between the two groups of ewes, considering all the periods.

Table 1: Mean (standard deviation) values of the parameters analyzed in lambs from sheared and non-sheared pregnant ewes

\begin{tabular}{|c|c|c|c|c|c|c|c|}
\hline \multirow{3}{*}{$\begin{array}{l}\text { N } \\
\text { Day post-partum }\end{array}$} & \multicolumn{3}{|c|}{ Sheared } & \multicolumn{3}{|c|}{ Non-sheared } & \multirow[t]{3}{*}{$\mathrm{P}^{*}$} \\
\hline & & 20 & & & 21 & & \\
\hline & 0 & $15-21$ & $22-45$ & 0 & $15-21$ & $22-45$ & \\
\hline Hematocrit (\%) & $44^{\mathrm{a}}(4.37)$ & $32^{\mathrm{a}}(2.86)$ & $29^{\mathrm{a}}(3.67)$ & $47^{\mathrm{b}}(6.99)$ & $33^{b}(3.94)$ & $31^{b}(2.56)$ & 0.04 \\
\hline Hemoglobin $(\mathrm{g} / \mathrm{dL})$ & $12.6^{\mathrm{a}}(1.89)$ & $10.8^{\mathrm{a}}(0.98)$ & $9.4^{\mathrm{a}}(2.20)$ & $13.8^{\mathrm{a}}(2.92)$ & $11.2^{\mathrm{b}}(1.34)$ & $10.6^{b}(0.87)$ & 0.03 \\
\hline Lactate $(\mathrm{mmol} / \mathrm{L})$ & $4.3(2.74)$ & & & $4.7(1.90)$ & & & 0.62 \\
\hline Glucose (mg/dL) & $51.1(28.22)$ & & & $51.5(33.98)$ & & & 0.97 \\
\hline Body weight (kg) & $5.46^{\mathrm{a}}(1.05)$ & $11.90^{\mathrm{a}}(2.83)$ & $15.66^{\circ}(4.11)$ & $4.53^{\mathrm{b}}(0.68)$ & $9.24^{\mathrm{b}}(1.66)$ & $13.26^{\mathrm{b}}(2.09)$ & 0.01 \\
\hline
\end{tabular}


Table 2: Mean (standard deviation) values of the parameters analyzed in sheared and non-sheared pregnant ewes

\begin{tabular}{|c|c|c|c|c|c|c|c|}
\hline \multirow[b]{2}{*}{$\mathbf{N}$} & \multicolumn{3}{|c|}{ Sheared } & \multicolumn{3}{|c|}{ Non-sheared } & \multirow[t]{2}{*}{$P^{*}$} \\
\hline & & 19 & & & 20 & & \\
\hline Day post-partum & 0 & $15-21$ & $22-45$ & 0 & $15-21$ & $22-45$ & \\
\hline Placenta weight (g) & $508.7^{\mathrm{a}}(127.3)$ & & & $403.7^{\mathrm{b}}(141.6)$ & & & 0.027 \\
\hline Body condition score & $2.80(0.63)$ & $2.40(0.50)$ & $2.10(0.46)$ & $3.00(0.64)$ & $2.50(0.66)$ & $2.2(0.60)$ & 0.349 \\
\hline $\mathrm{BHB}^{1}(\mathrm{mmol} / \mathrm{L})$ & $0.53(0.17)$ & $0.55(0.13)$ & $0.59(0.14)$ & $0.52(0.26)$ & $0.53(0.18)$ & $0.53(0.13)$ & 0.602 \\
\hline Milk yield (L/day) & & $1.27^{\mathrm{a}}(0.31)$ & $1.51^{\mathrm{a}}(0.3)$ & & $0.91^{\mathrm{b}}(0.24)$ & $0.96^{b}(0.24)$ & 0.011 \\
\hline
\end{tabular}

* Probability values between sheared and non-sheared ewes for all periods. Different letters indicate significant differences between sheared and non-sheared ewes for each correspondent period.

${ }^{1}$ Beta-hydroxybutyrate

\section{Discussion}

Shearing of sheep during gestation in this experiment affected hematological parameters of lambs. Hematocrit and hemoglobin values were lower in lambs from sheared ewes than in those from nonsheared ewes. Mellor \& Murray ${ }^{(19)}$ and Mellor ${ }^{(12)}$ justified the higher hematocrit in newborn lambs from non-sheared sheep as a compensatory effect to the diminished blood contribution to the fetus and the resulting chronic hypoxia, which may lead to a lesser growth of the placenta. However, the hematological parameters of the lambs in this experiment had values within the reference for the species, which makes it difficult to state that the lambs actually suffered chronic hypoxia or even low placental growth. Besides, other mechanisms could contribute to these results, as the hydration condition of the animals ${ }^{(20)}$. Therefore, more studies are necessary to elucidate the difference of hematocrit and hemoglobin in lambs born from sheared or non-sheared ewes.

In lambs, fetal hypoxia and/or low placental growth may result in higher serum concentrations of lactate resulting from a fetal anaerobiosis condition ${ }^{(19)}$. The general mean values of serum lactate in this experiment were $4.5 \mathrm{mmol} / \mathrm{L}$, which were below the values found by Barlow et al. ${ }^{(21)}$ in newborn lambs with chronic fetal hypoxia $(8.7 \mathrm{mmol} / \mathrm{L})$. Although lactate values of lambs from non-sheared ewes were numerically higher than those of lambs from sheared ewes, no statistical difference was detected. In placental hypoxia situation, it is believed an efficient regulatory mechanism takes place in metabolism of glucose and lactate, the main energy metabolites of fetus and placenta ${ }^{(22,23)}$. The needs of glucose for placenta, uterus and fetus represent up to $70 \%$ of the available glucose of the pregnant ewe. Only $46 \%$ of the energy needs for the fetus are satisfied by glucose, $20 \%$ comes from lactate and $25 \%$ from amino acids ${ }^{(22)}$. This means that many other factors may influence the mechanism of placenta growth, besides glucose contribution ${ }^{(24,13)}$. Symonds et al. ${ }^{(13)}$ suggested shearing would provoke a greater stimulus for food intake in sheep exposed to cold temperature, causing an increase of nutrients supplied to the fetus and placenta.

Birth weight of lambs from sheared ewes was 1,980 $\mathrm{g}(18 \%)$ higher than in lambs of the control group. This finding confirms previous works that reported an increase of $700 \mathrm{~g}$ and $710 \mathrm{~g}$ in the body weight of lambs from ewes sheared at $70^{(10)}$ and at 74 days of pregnancy ${ }^{(25)}$, respectively. 
Another two studies reported a mean body weight increase at birth of 1,400 g, suggesting shearing ewes at 53 days of pregnancy contribute to a greater fetal and placental development ${ }^{(26)}$. In the present study, lambs from the group of sheared ewes kept the body weight difference up to the $5^{\text {th }}$ week of life, and they were $15.3 \%$ heavier at wean than the lambs coming from non-sheared ewes. This result agrees with other studies that showed lambs from sheared ewes were $16.2 \%$ heavier at weaning than lambs from non-sheared ewes ${ }^{(26)}$. Other studies pointed out shearing ewes during pregnancy results in lambs 4.3 to $6.5 \%$ heavier than lambs from non-sheared sheep ${ }^{(9,27)}$.

Placenta weight in the group of sheared ewes was $105 \mathrm{~g}(20.6 \%)$ higher than in the control group. It is believed that the effect of shearing on placenta size occurs when it is carried out before the placentation period is complete ${ }^{(28)}$. Banchero et al. ${ }^{(5)}$ found an increase of $16 \%$ in the placenta weight in ewes sheared at 70 days of pregnancy, with a resulting increase of $8.2 \%$ in the body weight of the newborn lambs. Most works suggest shearing, when carry out up to 90 days of pregnancy, can contribute to a higher development of fetus and placenta ${ }^{(12)}$.

Many studies suggest body condition score (BCS) is a precise and practical indicator for evaluating the nutritional condition of the flock ${ }^{(29,30)}$, with a strong correlation between body condition of the ewe and conception rate ${ }^{(25)}$. However, BCS seemed to have no influence on the weight at birth of lambs. In our study, there was no difference between BCS in the groups of ewes, suggesting that shearing during pregnancy does not affect BCS of sheep and that the difference of body weight of the newborn lambs was not a result of ewes' BCS. We observed a reduction in BCS along the lactation period in both groups of ewes, which is probably a consequence of a negative energy balance during that period.

Serum values of BHB are a reliable parameter to indicate energy balance in ruminants ${ }^{(31)}$. BHB indicates the mobilization of energy reserves to provide energy needs during lactation and is a useful tool to indicate the nutritional status of pregnant ewes and to be related with body weight of lambs at birth ${ }^{(17)}$. In the present experiment, no difference was observed in BHB serum values of both groups of sheep, which suggests there was no influence of this metabolite in the weight of lambs at birth. We observed BCS values varied in an inverse way with serum concentration of BHB when all animals were considered. This represents a loss of body condition with lactation, concomitant with a higher lipomobilization. The results of BHB also suggest that this lipomobilization and ketone bodies generation did not provoke a ketosis condition, which occurs when BHB is higher than $1.0 \mathrm{mmol} / \mathrm{L}^{(32)}$.

Sheared ewes had a milk yield $323.5 \mathrm{~mL} /$ day $(26 \%)$ higher than non-sheared ewes. This finding agrees with the study by Sphor et al. ${ }^{(26)}$, who found a mean increase of $22.2 \%$ in the milk yield of ewes that were sheared at 53 days of pregnancy compared to non-sheared ewes.

Finally, we verified lambs from sheared ewes were more active, as $78 \%$ of them fed in the first hour of life compared to only $21 \%$ of lambs from control group, suggesting more vigor and a greater stimulus to the mother to produce more $\operatorname{milk}^{(5)}$.

In conclusion, Corriedale sheep raised under extensive system, sheared around 74 days of pregnancy, showed more efficiency in developing heavier lambs at birth and during the initial phase of growing, consequently minimizing the risk factors that contribute to perinatal mortality. The weights of placenta, newborn lambs and weaned lambs were directly influenced by shearing and may contribute to obtain better productive indexes. Sheared sheep produces more milk during lactation, although this effect of shearing needs to be elucidated. 


\section{Acknowledgments}

The authors are grateful to João Feliz Duarte de Moraes for his assistance in statistical analysis and to Dr. Cristina Dreyer and Fernando Paiva Chapon for their help during the sampling procedures.

\section{References}

1. Nóbrega Jr JE, Riet-Correa F, Nóbrega RS, Medeiros JM, Vasconcelos JS, Simões SVD, Tabosa M. Mortalidade perinatal de cordeiros no semi-árido da Paraíba. Pesquisa Veterinária Brasileira. 2005; 25: 171178.

2. Riet-Correa F, Méndez MC. Mortalidade perinatal em ovinos. In: Riet-Correa F, Schild AL, Lemos RAA, Borges JRJ (ed.) Doenças de Ruminantes e Eqüideos. $3^{\mathrm{a}}$ ed. Santa Maria: Palloti; 2007. p. 455-466.

3. Dalton DC, Knight TW, Johnson DL. Lamb survival in sheep bred in New Zealand Hill country. New Zealand Journal of Agriculture Research. 1980; 23: 167-173.

4. Kenyon PR, Morris ST, Revell DK, McCutcheon SN. Shearing during pregnancy - a review of a technique to increase lamb birth weight and survival in New Zealand pastoral farming systems. New Zealand Veterinary Journal. 2003; 51: 200-2007.

5. Banchero G, Vázquez A, Montossi F, Barbieri I, Quintans G. Pre-partum shearing of ewes under pastoral conditions improves the early vigour of both single and twin lambs. Animal Production Science. 2010; 50: 309-314.

6. Black HJ, Chestnutt DMB. Influence of shearing regime and grass silage quality on the performance of pregnant ewes. Animal Production. 1990; 51: 573-582.

7. Kenyon PR, Morel PCH, Morris ST. Effect of live weight and condition score of ewe at mating, and shearing mid-pregnancy, on birth weight and growth rates of twin lambs to weaning. New Zealand Veterinary Journal. 2004; 52: 145-149.

8. Kenyon PR, Sherlock RG, Morris ST, Morel PCH. The effect of mid- and late-pregnancy shearing of hoggets on lamb birth weight, weaning weight, survival rate, and wool follicle and fiber characteristics. Australian Journal of Agricultural Research. 2006; 57: 877-882.

9. Keady TWJ, Hanraha JP. Effects of shearing at housing, grass silage feed value and extended grazing herbage allowance on ewe and subsequent lamb performance. Animal. 2009; 3: 143-151.

10. Morris ST, McCutcheon SN. Selective enhancement of grow in twin foetuses by shearing ewes in early gestation. Animal Science. 1997; 65: 105-110.

11. Ribeiro LAO, Brito MA, Mattos RC. Ewes shorn and unshorn during pregnancy in South Brasil: effects on body condition score and lamb birth weight. Brazilian Journal of Veterinary Research and Animal Science. 2010; 47: 111-117.

12. Mellor DJ. Nutritional and placental determinants of foetal growth rate in sheep and consequences for the newborn lamb. British Veterinary Journal. 1983; 139: 307-324.

13. Symonds ME, Bryant MJ, Lomax MA. The effect of shearing on the energy metabolism of pregnant ewes. British Journal of Nutrition. 1986; 56: 635-643.

14. Burris MJ, Baugus CA. Milk consumption and growth of suckling lambs. Journal of Animal Science. 1955; 14: 186-191.

15. Souza ACK, Osório MTM, Osório JCS, Oliveira NMV, Clara MS, Souza M, Correa GF. Produção, composição química e características físicas do leite de ovinos da raça Corriedale. Revista Brasileira de Agrociência. 2005; 11: 73-77.

16. Cam, MA, Kuran M. Shearing pregnant ewes to improve lamb birth weight increases milk yield of ewes and lamb weaning weight. Asian-Australian Journal of Animal Science. 2004; 17: 1669-1673.

17. Russel A. Body condition scoring of sheep. In: Boden E. (ed.) Sheep and goat practice. London: Bailliere 
Tindall; 1991. p.3-10.

18. Doney JM, Peart JN, Smith WF, Louda F. A consideration of the technique for estimation of milk yield by suckled sheep and a comparison of estimates obtained by two methods in relation to the effect of breed, level of production and stage of lactation. Journal of Agricultural Science. 1979; 92: 123-132.

19. Mellor DJ, Murray L. Effects of placental weight and maternal nutrition on the growth rates of individual fetuses in single and twin bearing ewes during late pregnancy. Research in Veterinary Science. 1981; 30: 198-204.

20. Lacerda RM, Soto-Blanco B. Determinação das variantes de hemoglobina em ovinos mestiços Santa Inês. Caatinga. 2006; 19: 345-349.

21. Barlow RM, Gardiner AC, Angus KW, Gilmour JS, Mellor DJ, Cuthbertson JC, Newlands G, Thompson R. A clinical, biochemical and pathological study of perinatal lambs in commercial flock. Veterinary Record. 1987; 120: 357-362.

22. Bell WA, Ehrhardt A. Regulation of placental nutrient transport and implications for fetal growth. Nutrition Research Reviews. 2002; 15: 211-230.

23. Donnelly L, Campling G. Functions of the placenta. Anaesthesia and Intensive Care Medicine. 2008; 9: 124-127.

24. Brolio MP, Ambrósio CE, Franciolli AR, Morini AC, Guerra RR, Miglino MA. A barreira placentária e sua função de transferência nutricional. Revista Brasileira de Reprodução Animal. 2010; 34: 222-232.

25. Ribeiro LAO, Gregory RM, Mattos RC. Prenhez em rebanhos ovinos do Rio Grande do Sul. Ciência Rural. 2002; 32: 637-641.

26. Sphor L, Banchero G, Correa G, Osório MTM, Quintans G. Early prepartum shearing increases milk production of wool sheep and the weight of the lambs at birth and weaning. Small Ruminant Research. 2011; 99: 44-47.

27. Morris ST, Kenyon PR, Burnham DL, McCutcheon SN. The influence of pre-lamb shearing on lamb birth weight and survival. Proceeding of the New Zealand Grasslands Association. 1999; 61: 95-98.

28. Ehrhardt RA, Bell AW. Growth and metabolism of the ovine placenta during mid-gestation. Placenta. 1995; 16: 727-741.

29. Ducker MJ, Boyd JS. The effect of body size and body condition on the ovulation rate of ewes. Animal Production. 1977; 24: 377-385.

30. Gunn RG, Doney JM, Smith WF. The effect of level of pre-mating nutrition on ovulatory rate in Scottish blackface ewes in different body conditions at mating. Animal Production. 1984; 39: 235-239.

31. Caldeira RM. Monitoring the adequacy of feeding plan and nutritional status in ewes. Revista Portuguesa de Ciências Veterinárias. 2005; 100: 125-139.

32. Aitken ID. Disease of sheep. $4^{\text {th }}$ ed. London: Blackwell Publishing 2007. p. 602-603. 